\title{
English Teachers' Strategy in Teaching Writing Descriptive Text to Students of All-Grades at Junior High School
}

\author{
* Reza Luthfi \\ ** Berlin Sibarani
}

\begin{abstract}
This research was aimed at describing the extent to which strategy does the teachers use in teaching descriptive writing to students at Junior High School and finds out the reasons underlying the teachers using certain theory. The strategy which the teachers use was analyzed by following the theory of Johns' Scaffolding Strategy (2010). Scaffolding Strategy divided into Explicit Implementation consist of three types namely (1) modeling; (2) joint negotiation and (3) independent construction. And the other one is Implicit Implementation which consists of four types namely (1) dimly felt of sense; (2) begin composing; (3) course composing and (4) external feedback. The data was analyzed following Miles and Huberman theory of qualitative research (1994). The research findings showed that, the English teachers are using all three types of explicit implementation and only one type of implicit implementations, namely external feedback. And the reasons underlying teachers using these implementations are (1) the teachers want to vivid students' knowledge about the generic structure, language features and social functions of descriptive text, (2) teachers want the students to understand more and get familiar with descriptive text in real life, (3) teachers wants to know students' ability in applying their knowledge of descriptive text on their own-making descriptive text and (4) enlighten students on how to criticize their friends' work.
\end{abstract}

Keywords: Descriptive, scaffolding, explicit implementation, implicit implementation

\section{*Graduate Status \\ ** Lecturer Status}




\section{Introduction}

Writing is a language skill that the students should be done easily and quickly, without extend many thought and effort. Writing skill is complex and sometimes difficult to teach, required mastery not only in the grammatical and theoretical device but also conceptual and judgmental elements. To teach writing to students, teacher should invite the students to practice writing and communicate knowledge and thought to form of text. Teacher can implement some strategies or methods to helps the students to be more interesting and enlightened students' idea and make learning writing more easily.

Hence, the research that relates to teachers' strategy in teaching writing descriptive was conducted in order to describe to what strategy do the teachers use in teaching descriptive writing and the reasons why do the teachers use certain strategy.

\section{Theoretical Review}

\section{The nature of Descriptive Text}

Description or descriptive etymology is derived from the word describe which means to draw, to illustrate or to picture object, place, person in order to have visual appearance of the object described (Wy. Dirgayasa, 2014) descriptive text has identification and description as generic structure (Gerrot and Wignell, 1995). The aim of description is to reveal character, set the scenes and to established the mood. There are four types 
of descriptive text to teach, namely (1) personal and commonsense description; (2) literary description; (3) animal reports and (4) information report. Teachers should do these things in teaching descriptive writing, namely (1) activate students' experience; (2) guiding the students to observe physical object; (3) ask the students to write down small description of first impression; (4) compare their description with others; (5) editing; (6) revising.

\begin{tabular}{|c|c|}
\hline \multicolumn{2}{|c|}{ Assessment Report } \\
\hline Genre's & Describing \\
\hline Text Type & Description \\
\hline \multicolumn{2}{|l|}{ Structure } \\
\hline \multicolumn{2}{|l|}{ Description of self } \\
\hline Classification & Name and age \\
\hline Appearance & $\begin{array}{l}\text { Description limited to family } \\
\text { characteristics }\end{array}$ \\
\hline Family & $\begin{array}{l}\text { Reference to family members } \\
\text { and pets }\end{array}$ \\
\hline Friends & $\begin{array}{l}\text { Reference and description of } \\
\text { friend and common interest }\end{array}$ \\
\hline \multicolumn{2}{|l|}{ Description of place } \\
\hline Appearance & $\begin{array}{l}\text { Describe the setting, location } \\
\text { and appearance of their home }\end{array}$ \\
\hline Naming the place & Identifies the place \\
\hline Features and happenings & $\begin{array}{l}\text { Limited description of map, } \\
\text { number account of happenings }\end{array}$ \\
\hline Text organization & $\begin{array}{l}\text { Separate paragraphs provided } \\
\text { for each description }\end{array}$ \\
\hline \multicolumn{2}{|l|}{ Grammar } \\
\hline Sentences construction & $\begin{array}{l}\text { Shows development through use } \\
\text { of some sentences which have } \\
\text { subordinate co-ordinate clauses }\end{array}$ \\
\hline Tenses & $\begin{array}{l}\text { Consistent use of present tense, } \\
\text { and if describing about past, it } \\
\text { uses past tense }\end{array}$ \\
\hline Descriptive noun groups & $\begin{array}{l}\text { Has made some attempt build } \\
\text { descriptions through noun } \\
\text { groups }\end{array}$ \\
\hline Adjectives & Requires further work \\
\hline
\end{tabular}




\begin{tabular}{|c|l|}
\hline Metaphoric action verbs & No evidence of use \\
\hline Adverbs & $\begin{array}{l}\text { No evidence due to absence of } \\
\text { description of events }\end{array}$ \\
\hline Metaphors and similes & Use of metaphors and similes \\
\hline Spelling/punctuation & $\begin{array}{l}\text { Spelling and punctuation } \\
\text { understanding. }\end{array}$ \\
\hline
\end{tabular}

Table of Descriptive Writing Assessment

\section{Scaffolding Strategy in Teaching How to Write Descriptive Text}

Scaffolding strategy is invented by Johns (2010) which means to help by structurally. The strategy can be implemented both implicitly and explicitly

1. Explicit Implementation

In explicit implementation, the strategy divided into three types namely

a) Modelling

Modeling is used to build up example model of genre so it can help learners to explore the social purpose of the text, it is prototypical elements of structure, and its distinctive language features

b) Joint Negotiation

Teacher prepares learners in production a new text that focus in genre. Teacher and students arrange a new text together, drawing on shared knowledge of both the learning context itself and the structure and features of the genre.

c) Independent Construction 
students are working in own text using drafting, conferencing, editing, and publishing processes. Many teachers have used the strategies suggested in the cycle, but their pedagogies have not lockstep or rigidly applied

2. Implicit Implementation

Implicit implementation is based on an understanding of genre knowledge as "tacit" knowledge, begins with students' dimly felt of sense of the new genre composing process and in the course of the unfolding text.

Writers create genre in the course of producing it, guided by a sense of genre that is modified through assignment, class lectures and discussion, and feedback on writing.

Implicit implementation divided into four, namely:

a) Learners approach with dimly felt of sense

b) Composing by focus on the specific content

c) Dimly felt of sense in the course of composing

d) External feedback

\section{Methodology}

\section{Types of Research}

In accordance with the objective of the research this research was conducted by applying qualitative research method with descriptive design. Qualitative research is a generic term for an array of educational research approaches, 
such as ethnography, naturalistic inquiry, narrative research, case studies, interpretive research, fieldwork, field studies, and participant observation. Qualitative research seeks to understand a phenomenon by focusing on the total picture rather than breaking it down into variables. The goal is a holistic picture and depth of understanding than a numeric analysis of data. (Ary, 2010: 23)

\section{Research Subject}

The subject of this study is the English teacher itself. The teacher who chose in this study is the teacher who teach writing descriptive at that school. The teacher was chosen randomly by the writer.

\section{Technique of Analyzing Data}

The data of this research will be analyzed by using Miles, Huberman and Saldana (1994)

Data Condensation

This step refers to the process of selecting, focusing, simplifying, abstracting, and/or transforming the data that appear in the full corpus (body) of the written - up field notes, interview transcripts, documents, and other empirical materials. After writer do observation and interview, the data will be transcribing into the document data by the writer.

\section{Data Display}

Generically, a display is an organized, compressed assembly of information that allows conclusion drawing and action. In this step, the writer displays and 
explain the findings in chart, and constructing a descriptive from the data that has found to response the research problem. Also, the writer was described the phenomenon based on Knapp theory.

Drawing \& Verifying Conclusion

Conclusion lightly, maintaining openness and skepticism, but still there, vague at first then increasingly explicit and grounded. Conclusions are also verified as the analyst proceeds. Verification may be as brief as a fleeting second thought crossing the analyst's mind during writing, with a short excursion back to the field notes. or it may be thorough and elaborate, with lengthy argumentation and review among colleagues to develop "intersubjective consensus" or with extensive efforts to replicate a finding in another data set.

\section{Result and Discussion}

\section{Research Findings Description}

\section{Teachers' Strategy in Teaching Writing Descriptive Text}

\begin{tabular}{|c|c|c|c|c|c|}
\hline \multirow{2}{*}{ No } & \multirow{2}{*}{ Teachers } & \multicolumn{3}{|c|}{ Explicit Implementation } & \multirow{2}{*}{$\begin{array}{c}\begin{array}{c}\text { Implicit } \\
\text { Implementation }\end{array} \\
\text { External } \\
\text { Feedback }\end{array}$} \\
\hline & & Modelling & $\begin{array}{c}\text { Joint } \\
\text { Negotiation }\end{array}$ & $\begin{array}{l}\text { Independent } \\
\text { Construction }\end{array}$ & \\
\hline 1 & $\begin{array}{l}\text { Bambang } \\
\text { (BB) }\end{array}$ & $\begin{array}{l}\text { In this } \\
\text { type, the } \\
\text { teacher } \\
\text { builds up } \\
\text { students } \\
\text { experience } \\
\text { by } \\
\text { showing } \\
\text { example }\end{array}$ & $\begin{array}{l}\text { The teacher } \\
\text { asks the } \\
\text { students to } \\
\text { analyze the } \\
\text { picture he } \\
\text { already } \\
\text { gave in the } \\
\text { first time. }\end{array}$ & $\begin{array}{l}\text { The teacher } \\
\text { asking the } \\
\text { students to } \\
\text { write their } \\
\text { own making } \\
\text { descriptive } \\
\text { text under the } \\
\text { theme of } \\
\text { school }\end{array}$ & $\begin{array}{l}\text { teacher asked } \\
\text { the students to } \\
\text { exchange their } \\
\text { descriptive } \\
\text { writing to the } \\
\text { other friend }\end{array}$ \\
\hline
\end{tabular}




\begin{tabular}{|c|c|c|c|c|c|}
\hline & & $\begin{array}{l}\text { of } \\
\text { descriptive }\end{array}$ & & & \\
\hline 2 & $\begin{array}{l}\text { Sonang } \\
\text { Sitorus }\end{array}$ & $\begin{array}{l}\text { In this } \\
\text { type, the } \\
\text { teacher } \\
\text { explaining } \\
\text { about } \\
\text { generic } \\
\text { structure } \\
\text { and } \\
\text { language } \\
\text { features of } \\
\text { descriptive } \\
\text { text }\end{array}$ & $\begin{array}{l}\text { The teacher } \\
\text { activated } \\
\text { students' } \\
\text { knowledge } \\
\text { of the text } \\
\text { by asking } \\
\text { them to read } \\
\text { the text then } \\
\text { analyzed } \\
\text { the } \\
\text { language } \\
\text { features }\end{array}$ & $\begin{array}{l}\text { The teacher } \\
\text { is asking the } \\
\text { students to } \\
\text { make their } \\
\text { descriptive } \\
\text { text about } \\
\text { tourist } \\
\text { attraction that } \\
\text { they know }\end{array}$ & $\begin{array}{l}\text { the teacher } \\
\text { asked the } \\
\text { student to } \\
\text { evaluate their } \\
\text { friend's work }\end{array}$ \\
\hline 3 & Andy Arief & $\begin{array}{l}\text { The } \\
\text { teacher is } \\
\text { explaining } \\
\text { about the } \\
\text { definition, } \\
\text { generic } \\
\text { structure, } \\
\text { identificati } \\
\text { on of } \\
\text { descriptive } \\
\text { text }\end{array}$ & $\begin{array}{l}\text { The } \\
\text { teachers } \\
\text { showing a } \\
\text { picture and } \\
\text { then asking } \\
\text { the students } \\
\text { to analyze } \\
\text { the } \\
\text { language } \\
\text { feature and } \\
\text { generic } \\
\text { structure } \\
\text { from the } \\
\text { paragraph }\end{array}$ & $\begin{array}{l}\text { The teacher } \\
\text { was asking } \\
\text { the students } \\
\text { to make } \\
\text { descriptive } \\
\text { text about } \\
\text { students' } \\
\text { favorite } \\
\text { person, and } \\
\text { ask the } \\
\text { students to } \\
\text { come to the } \\
\text { front to read } \\
\text { it. }\end{array}$ & $\begin{array}{l}\text { the teacher was } \\
\text { asking the } \\
\text { students to } \\
\text { evaluate the } \\
\text { other students' } \\
\text { work }\end{array}$ \\
\hline
\end{tabular}

\section{Teachers' Reasons of Using the Strategy}

\begin{tabular}{|c|l|l|l|l|l|}
\hline \multirow{2}{*}{ No } & \multirow{2}{*}{ Teachers } & \multicolumn{3}{|c|}{ Explicit Implementation } & \multicolumn{1}{|c|}{$\begin{array}{l}\text { Implicit } \\
\text { Implementation }\end{array}$} \\
\cline { 3 - 6 } & Modelling & $\begin{array}{l}\text { Joint } \\
\text { Negotiation }\end{array}$ & $\begin{array}{l}\text { Independent } \\
\text { Construction }\end{array}$ & $\begin{array}{l}\text { External } \\
\text { Feedback }\end{array}$ \\
\hline \multirow{2}{*}{1} & Bambang & $\begin{array}{l}\text { The } \\
\text { teachers } \\
\text { giving } \\
\text { explanation } \\
\text { and and }\end{array}$ & $\begin{array}{l}\text { Teachers } \\
\text { prepared } \\
\text { the } \\
\text { students' } \\
\text { mind and }\end{array}$ & $\begin{array}{l}\text { The teacher } \\
\text { believes that } \\
\text { the students } \\
\text { can } \\
\text { understand }\end{array}$ & $\begin{array}{l}\text { can } \\
\text { increasing their } \\
\text { aboul what is } \\
\text { right and what }\end{array}$ \\
\hline
\end{tabular}




\begin{tabular}{|c|c|c|c|c|c|}
\hline & & $\begin{array}{l}\text { example of } \\
\text { descriptive } \\
\text { text so } \\
\text { students } \\
\text { can vivid } \\
\text { their } \\
\text { imagination } \\
\text { about the } \\
\text { class, } \\
\text { which is } \\
\text { known as } \\
\text { modeling } \\
\text { strategy }\end{array}$ & $\begin{array}{l}\text { imagination } \\
\text { by giving } \\
\text { example } \\
\text { and also } \\
\text { giving } \\
\text { explanation } \\
\text { about the } \\
\text { example. }\end{array}$ & $\begin{array}{l}\text { more about } \\
\text { descriptive } \\
\text { writing }\end{array}$ & $\begin{array}{l}\text { is wrong while } \\
\text { writing } \\
\text { descriptive text. }\end{array}$ \\
\hline 2 & $\begin{array}{l}\text { Sonang } \\
\text { Sitorus } \\
(\mathrm{SS})\end{array}$ & $\begin{array}{l}\text { The teacher } \\
\text { wants to } \\
\text { build - up } \\
\text { students' } \\
\text { knowledge } \\
\text { about the } \\
\text { generic } \\
\text { structure } \\
\text { and } \\
\text { language } \\
\text { features of } \\
\text { descriptive } \\
\text { text. }\end{array}$ & $\begin{array}{l}\text { The teacher } \\
\text { wants to } \\
\text { vivid the } \\
\text { students' } \\
\text { knowledge } \\
\text { about } \\
\text { descriptive } \\
\text { writing by } \\
\text { analyzing } \\
\text { the } \\
\text { structure } \\
\text { and so the } \\
\text { students are } \\
\text { able to feel } \\
\text { familiar } \\
\text { about } \\
\text { descriptive } \\
\text { text. }\end{array}$ & $\begin{array}{l}\text { the teachers } \\
\text { believe it } \\
\text { will help the } \\
\text { student to } \\
\text { implement } \\
\text { the } \\
\text { knowledge } \\
\text { that they } \\
\text { have already } \\
\text { got from the } \\
\text { explanation }\end{array}$ & $\begin{array}{l}\text { The teacher } \\
\text { wants the } \\
\text { students can } \\
\text { make } \\
\text { correction } \\
\text { about their } \\
\text { friends' work } \\
\text { and also to } \\
\text { improve their } \\
\text { confidence }\end{array}$ \\
\hline 3 & $\begin{array}{l}\text { Andy } \\
\text { Arief } \\
\text { (AA) }\end{array}$ & $\begin{array}{l}\text { the teacher } \\
\text { wants to } \\
\text { know the } \\
\text { level of } \\
\text { knowledge } \\
\text { from the } \\
\text { students } \\
\text { and to build } \\
\text { up the } \\
\text { students' } \\
\text { critical } \\
\text { thinking }\end{array}$ & $\begin{array}{l}\text { wants to } \\
\text { know how } \\
\text { well do the } \\
\text { students } \\
\text { understand } \\
\text { the } \\
\text { application } \\
\text { of generic } \\
\text { structure } \\
\text { and } \\
\text { language } \\
\text { features on } \\
\text { the real }\end{array}$ & $\begin{array}{l}\text { The teacher } \\
\text { wants to } \\
\text { know how } \\
\text { well do the } \\
\text { students } \\
\text { applicating } \\
\text { the } \\
\text { knowledge } \\
\text { they gained } \\
\text { from his } \\
\text { explanation } \\
\text { and to } \\
\text { enrich the } \\
\text { students' }\end{array}$ & $\begin{array}{l}\text { The teacher } \\
\text { wants to } \\
\text { enrich } \\
\text { students' } \\
\text { critical thinking } \\
\text { and to scoring } \\
\text { the others' } \\
\text { work }\end{array}$ \\
\hline
\end{tabular}




\begin{tabular}{|l|l|l|l|}
\hline & text. & $\begin{array}{l}\text { confidence } \\
\text { and public } \\
\text { speaking in } \\
\text { front of the } \\
\text { class. }\end{array}$ & \\
\hline
\end{tabular}

\section{Discussion}

In theory, there is scaffolding strategy that can be used as a strategy in teaching descriptive writing. And in scaffolding strategy, it consists of two implementations namely (1) explicit implementation and (2) implicit implementation. In explicit implementation there are three types which are (1) modeling, (2) joint negotiation and (3) independent construction. While implicit implementation consists of four types, they are (1) dimly felt of sense, (2) begin of composing (3) course composing (4) external feedback. In teaching learning process, the teachers used all three types of explicit implementation, and only one type of implicit implementation.

Based on the researcher interview with the teachers, the reasons of why the teachers were using this strategy in teaching writing descriptive are the teachers want to know and enlighten students' knowledge of generic structure, language features and social functions of descriptive text, how well the students' understanding of the generic structure, language features and social functions of descriptive text in real text, how well the students applying their knowledge about descriptive text on their own-making-descriptive text 
and practicing students' writing skill, and also want the students to scoring, and acknowledge their friends' work also to raise students' confidence.

\section{Conclusions and Suggestions}

\section{Conclusion}

Based on the findings of the research and discussions in chapter IV, then proposed the following conclusion.

1. The strategy that the teachers applied in teaching writing descriptive text at SMP Negeri 3 Tebing Tinggi was Scaffolding Strategy from Johns (2010). From Johns' Scaffolding Strategy, the teachers are using all three of explicit implementation namely (1) modeling, (2) joint negotiation (3) independent construction. And also using one type of implicit implementation namely external feedback.

2. The reasons why the teacher applied the strategy are:

i. In modelling, the teacher, the teachers' want to enlighten students' knowledge about generic structures, language features and social functions of descriptive text.

ii. In joint negotiation, the teachers' want to know the students' understanding about descriptive text.

iii. In independent construction, the teachers' want to know how well the students applying their knowledge of descriptive text by asking them to write their own-making descriptive text. 
iv. In external feedback, the teachers want to enlighten the students of how to criticize their friends' work.

\section{Suggestions}

Based on the conclusion above, the researcher would offer some suggestions that hopefully will be useful for:

1. Teachers

This strategy can be applied in classroom because it can help teachers in teaching descriptive writing and also improve the teachers' quality in teaching.

2. Students

By using this strategy, teachers can deliver the material more effectively and the students can understand the materials even better.

3. Next researcher

The researcher wishes that other researcher could conduct this research in wider area. So, the teachers can get more effective strategy in teaching English especially descriptive writing. 


\section{REFERENCES}

Ary, D (2010) Introduction to Research in Education: $8^{\text {th }}$ Edition. Canada: Wadsworth Cengage Learning, Nelson Education, Ltd.

Bawarshi, and Reiff (2010) Genre: An Introduction to History, Theory, Research and Pedagogy. Indiana: Parlor Press LLC.

Clay, M. The Reading Behavior of Five - year - old Children: A Research Report. New Zealand Journal of Educational Studies, 2 (1966). pp. 11 31.

Gerrot. L. Wignell P (1995) Making Sense of Functional Grammar: An Introductory Workbook. Sydney: Antipodean Educational Enterprise.

Johns, A. M (2010). Genre in the Classroom Multiple Perspectives. New Jersey: Lawrence Erlbaum Associates.

Kellogg, R. T (2008) Training Writing Skill: A Cognitive Developmental Perspective. Journal of Writing Research.

Knapp, P (2005) Genre, Text, Grammar: Technologies for Teaching and Assessing Writing. New South Wales: University of New South Wales Press, Ltd.

Knapp, P (1996) Our Place: Connecting Text and Grammar. New South Wales: Blake Education Printing Creation.

Kroll, B. M (1981) Developmental Relationships between Speaking - Writing. In B. M. Kroll \& R. J Vann (Eds.), Exploring Speaking - Writing 
Relationships: Connections and Contrasts (pp. 32 - 54). Urbana, IL: National Council of Teachers of English

Luria, A (1929/1978). The Development of Writing in a Child. In M. Cole (Ed.), The Selected Writings of A. R. Luria (pp. 146 - 194). New York: M. E. Sharpe

Macken M. et al. 1990. A Genre - Based Approach to Teaching Writing. Australia: Literacy \& Education Research Network.

Miles, M.B., et al (2014) Qualitative Data Analysis: A Methods Sourcebook $\left(3^{\text {rd }}\right.$ Ed.) California: SAGE Publications

Parera, K. (1984) Children's Writing and Reading. Analyzing Classroom Language. Basil Blackwell in association with André Deutsch.

Painter, C (1996) The Development of Language as a resource for thinking: A linguistic view of learning. London: Longman Publishing.

Read, C (1986) Children's Creative Spelling. London: Routledge \& Kegan Paul.

Scardamalia, M., Bereiter, C (1987) Knowledge Telling and Knowledge Transforming in Written Composition. Advanced in Applied Psycholinguistics, 2, $142-175$.

Schnnittke, E (2014) Birch Bark Letters Agains the Background of Written Language Acquisition. Moscow: National Research University Press.

Sibarani, B. Aziz, M. H. The Developmental of Exposition Paragraph Writing Ability of Grade 10 - 12 Students of MAN 2 Model Medan. Journal of Language, Literature and Teaching Vol 1, No. 1. (2019). pp. $30-41$. 
Sugiharti, Amin. (2018). Implementation of Scaffolding Strategy to Teach Reading in MTsN Paron (Naturalistic Study). Surakarta: Universitas Muhammadiyah Surakarta.

Utami, T.A (2014) Improving the Ability in Writing Descriptive Texts Through Brainstorming Technique for Grade VIII Students at SMPN 1 Piyungan. Yogyakarta: Yogyakarta State University. 